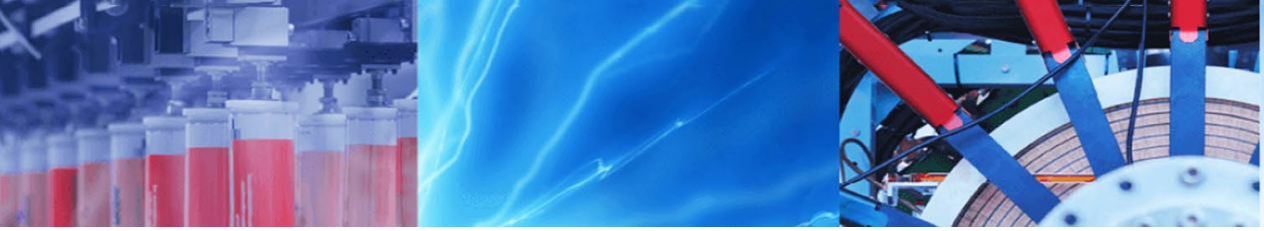

Research Article

\title{
Landslides susceptibility assessment by analytical network process: a case study for Kuttiyadi river basin (Western Ghats, southern India)
}

\author{
T. V. Swetha ${ }^{1}$ (D) Girish Gopinath ${ }^{1,2}(\mathbb{D}$
}

Received: 21 May 2020 / Accepted: 22 September 2020 / Published online: 6 October 2020

(c) Springer Nature Switzerland AG 2020

\begin{abstract}
In the case of Western Ghats of Kerala located in southern India, landslides become the most devastating hazard during the monsoon season is mainly because of intense rainfall. The recent landslides struck in the months of June and August 2018 were the worst in the history of the state as the damages to life and property happened were very dangerous. From this evidences, being a landslide-prone area a hazard zonation attempted using the terrain susceptibility concept for highlands of Kuttiyadi river basin is a part of Western Ghats in Kozhikode district with a maximum elevation of $1640 \mathrm{~m}$ above MSL. Through landslide susceptibility mapping, the assessment of areas likely to have or probable to landslides in the future identified using geospatial and multi-criteria decision-making (MCDM) tool mix. This work explores the usage of the MCDM tool-analytical network process (ANP)-based decision-making approach to determine the relationship between each landslide conditioning factors and to assign weight effectively. Factor maps of various landslide triggering parameters such as slope, soil, landuse, drainage density, stage of landform, lineament density, geology, and geomorphology were prepared and integrated through geospatial analyses in the GIS platform, and the study area $\left(318 \mathrm{~km}^{2}\right)$ is categorized into four classes of unstable $\left(121 \mathrm{~km}^{2}\right)$, moderately unstable $\left(76 \mathrm{~km}^{2}\right)$, stable to moderately stable $\left(124 \mathrm{~km}^{2}\right)$, high vulnerability $\left(67 \mathrm{~km}^{2}\right)$, and very high vulnerability $\left(74 \mathrm{~km}^{2}\right)$. The result of this work concluded that the application of ANP is an effective tool to weight the factors causing landslides and to generate landslide susceptibility zonation map with maximum accuracy using geospatial technology. The validation of output data with landslide inventory data is satisfying it.
\end{abstract}

Keywords Geospatial · MCDM ·ANP· Landslide susceptibility-Western Ghats

\section{Introduction}

Landslides are the most frequent natural disasters around the world, it is mainly due to the expansion of urban and man-made structures into potentially hazardous areas, and damage to infrastructure and human life due to this geohazard is very huge [19]. The downslope movement of materials like rocks or soil occurring on a surface of rupture or weak zone of intense shear strain due to the force of gravity acting on its results in the powerful geohazard is known as a landslide. Based on the type of the movement, type of material landslides can be classified into several types such as fall, topple, slide, spread, flows, and creep and it can be described as rock falls, debris flow, earth flow, etc. [15]. Several factors can cause a landslide event like heavy rainfall, steepness of the slope, soil erosion, weathering, disturbance in week structural features like joints, bedding plane, etc. Primarily, landslides are associated with heavy rain fed areas in mountainous regions and weathering and erosion are considered as one of

T. V. Swetha, tvthulasy@gmail.com; Girish Gopinath, ggkufos@gmail.com | 1 Geomatics Division, Centre for Water Resources Development and Management, Calicut, Kerala 673 571, India. ${ }^{2}$ Kerala University of Fisheries and Ocean Studies, Kochi, Kerala 682508 , India. 
the natural cause for landslide in areas with the highest rainfall; increasing soil erosion wipes out the topsoil and lateral slope support facilitate unstable slope to intensify the damage of landslide events [22]. The processes like weathering have a direct relation to facilitating impulsive landslide events because varying weathering patterns can increase the thickness of loose unconsolidated soil formation from the basement rock, and several studies have proved the relationship between this geohazard and weathering [30, 35]. As landslides are spatial phenomena, the cartographic technique-based analysis is superlative than other measures. The cartographic analysis can provide output as different levels of maps, such as base maps providing information on the spatial location of the historic and recent landslide events, spatial distribution map of landslide triggering factors and after overlaying them, high level map like 'landslide susceptibility map' (LSM) can be derived. The purpose of susceptibility mapping is the interpretation of spatial likelihood of a risk phenomenon like landslide happens in a specific area or slope in a not determined date through the analysis of landslide triggering geo-environmental factors and correlation with past landslide inventory data [16].

Many works that have been reported on landslide susceptibility mapping using geospatial techniques (GISgeographical information system and satellite images) have been found as useful tools in landslide susceptibility mapping and for further studies on soil loss estimation, suitable site suggestions for the construction of the new building, and the disaster management planning [26]. There are many methods designed by researchers for the assessment of slope stability, the innovative techniques like geospatial and geophysical techniques, modeling of triggering factors, landslide reactivation, implementation of geotechnical design, and construction procedures in landslide-prone areas [18]. The slope mass rating (SMR) classification system has used to investigate slope stability in gas flare sites in Assalouyeh, South of Iran, and classified the slopes into stable, unstable, and need attention classes [5]. Many geotechnical investigations have been carried out by researchers [1] to evaluate the stability of the study region. In Turkey, a project site located in the vicinity of a Fault Zone, the coupled slope stability analysis has performed and suitable slope remediation methods are also suggested [20]. The slope stability analysis using numerical modeling and block theory method is consistent, and the slope is classified as "need attention" for the South Pars Gas Complex, Iran [6]. Before any geotechnical investigation for the determination of structurally controlled instabilities within the tunnel sections, slope stability assessment studies are pre-requisites [2]. The Q-slope system has an empirical method to predict rock slope stability, and correlation relationship assessment between $\mathrm{Q}$-slope and slope stability degree also possible [8]. Intense rainfall is considered as a prime factor for landslides, even though systematic integration of various surface features that trigger landslide hazard is a significant aspect in landslide hazard zonation study [31]. In the landslide susceptibility mapping of the Mawat area, NE Iraq, hypsometric integral also considered with other geological and environmental factors, it increased the accuracy of the LSI map [21]. Landslide susceptibility mapping can depict the division of land surface into zones of varying degrees of stability based on the influence of the causative factors [12, 32]. Landslide susceptibility mapping with the aid of GIS involves both qualitative and quantitative methods and are often useful for regional assessments, the most important factors such as slope, geological formation, soil type, rivers, and anthropogenic activities in the study area considered for landslide susceptibility assessment in clay areas of the south-eastern part of Norway [10]. The triggering factors for landslide like hypsometric integral, slope, drainage, rugged topography, rock type, etc., considered and identified that the northern and western parts of the Korucak sub-basin are under the highest-risk landslide zone [33].

The landslide susceptibility assessment map should be transferred to decision-makers to implement landslide loss-reduction strategies and to reduce the occurrence of landslide and to minimize their social and economic effects [4]. Several methods are used by many researchers to identify and depict a landslide susceptibility zones in various regions. To produce landslide susceptibility map of a study area in Greece, the analysis of seven landslide conditioning factors (elevation, slope, aspect, lithology, land cover, mean annual precipitation, and peak ground acceleration) was carried out using the GIS-based bivariate statistical index method and the study area is classified into five landslide susceptible zones [9].

A scientific approach for LSM using spatial inputs and GIS techniques (GIS) along with analytic network process (ANP) modeling is an excellent algorithm for understanding of the fragility or stability of an area in terms of landslides. The ANP implemented in the software 'Super Decisions' has been applied to various problems both to deal with decisions and to illustrate the uses of the new theory (www.superdecisions.com). To solve the problem of dependency among alternatives or criteria, ANP is one of the methods in MCDM technique that has proved itself to be a precise predictor through many studies related to business, sports, political, and many other social and environmental studies [29]. A combination of MCDM, likelihood ratio, and fuzzy logic at a regional and local level considered to prepare a landslide susceptibility map for the South pars Special Zone of Iran, and these data are used for landslide mitigation assessment and landuse planning in the identified landslide-prone areas [7]. In a case study 
at Izmir, Turkey, logistic regression, multi-criteria decision (MCDM), and likelihood ratio method were used to prepare landslide susceptibility maps, the logistic regression method identified as the most accurate one after the comparison study [3]. To map debris flow susceptibility, a less explored heuristic MCDM (multi-criteria decision making) method-analytical network process (ANP) is utilized to translate the rank of the factors influencing to occur debris flow to appropriate weights [27]. The impact of each of the factors responsible for the occurrence of the landslide is determined using the ANP method, and the hazard zonation map was prepared in a GIS environment [17]. The landslide susceptibility mapping (LSM) carried out in this study for highlands of the Kuttiyadi river basin is a part of Western Ghats in Kozhikode district, Kerala, southern India.

\section{Regional settings}

Physiographically, Kerala has divided into lowland, midland, and highland, based on the elevation of $<7.6 \mathrm{~m}$, 7.6-76 $\mathrm{m}$, and $>76 \mathrm{~m}$, respectively. The main focus of this study is the highlands of the Kuttiyadi river basin (KRB) located $11^{\circ} 30^{\prime} \mathrm{N}$ and $75^{\circ} 51^{\prime} \mathrm{E}$ of northern Kerala (Fig. 1). This study area is part of Western Ghats in Kozhikode, covering $318 \mathrm{~km}^{2}$ of KRB rise from a low altitude of $76 \mathrm{~m}$ up to $1640 \mathrm{~m}$. The chief tributaries such as Onipuzha, Thottilpalampuzha, Kadiyangadupuzha, Mannathilpuzha, and Madappalipuzha of KRB originate from different locations at this highland region and form the mainstream Kuttiyadi River and drain into the Arabian Sea at Kottakal. The highlands of KRB receive a mean annual rainfall of $5170 \mathrm{~mm}$. About $60 \%$ of the annual rainfall is contributed during SW monsoon and $30 \%$ during the NE monsoon. The name of KRB is famous with two dams located at Peruvannamuzhi and the other at Kakkayam in the highlands zone.

\section{Materials and methods}

The main objective of this work is to use GIS and multicriteria decision-making (MCDM) technique-analytical network process (ANP) for landslide susceptibility mapping (LSM) for the Western Ghats parts of Kuttiyadi river basin, Kerala, southern India. The methodology opted for landslide susceptibility mapping using GIS, and ANP tools is clearly illustrated in the below flowchart (Fig. 2). The spatial database of landslide conditioning factors like rainfall, slope, soil, geological stage of landform (from hypsometric integral), drainage density, lineament density,

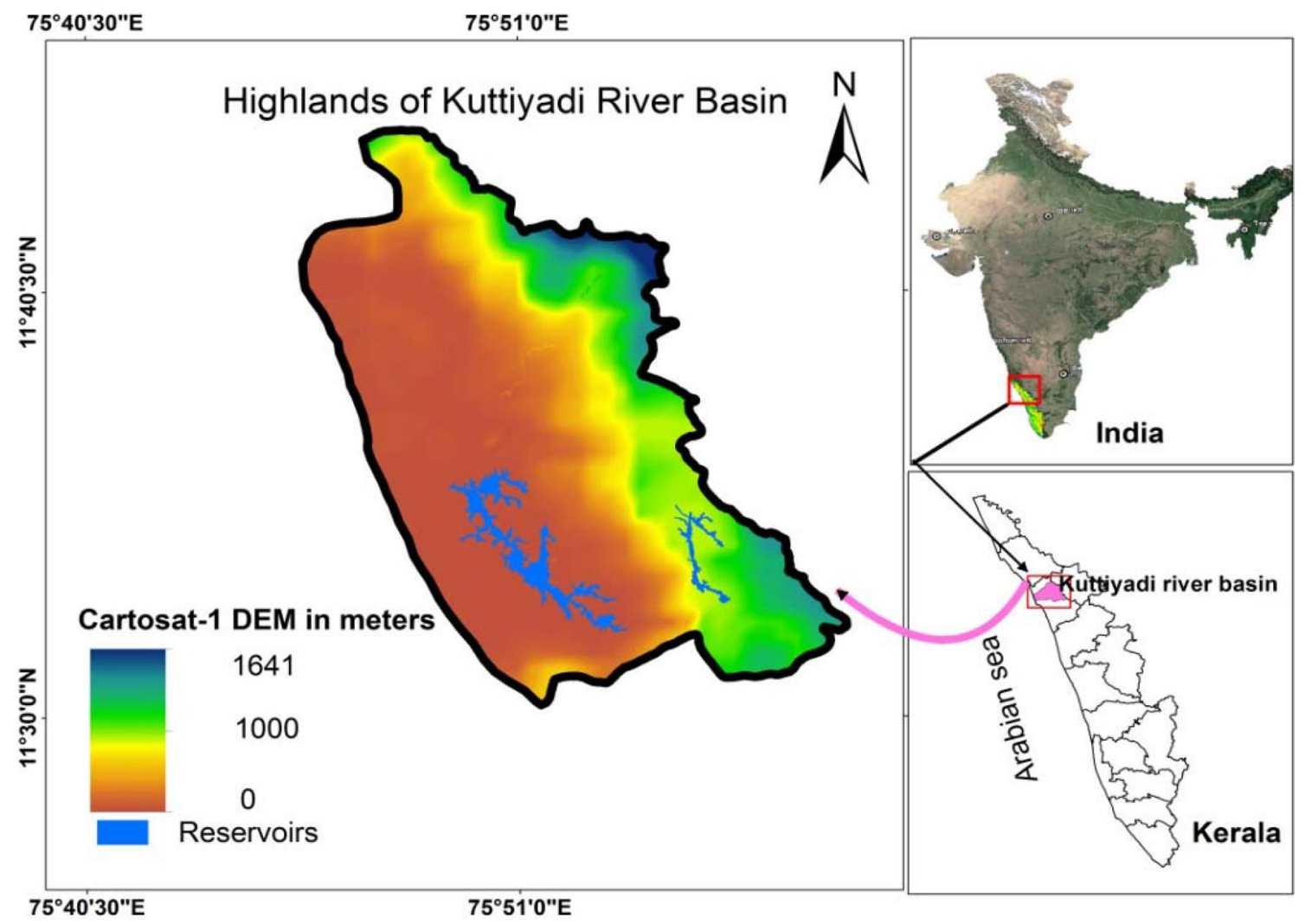

Fig. 1 Study area-Highlands of Kuttiyadi River Basin 


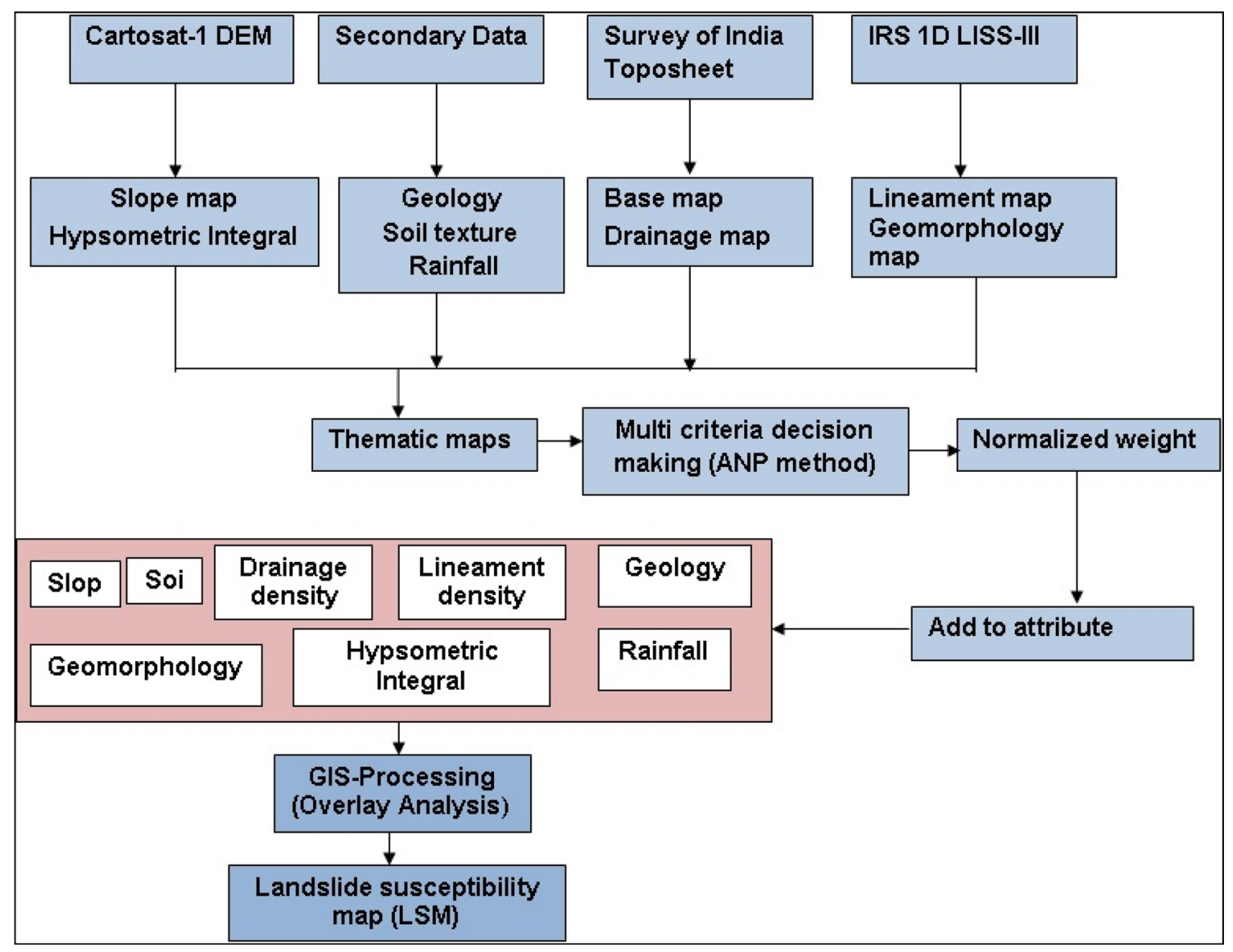

Fig. 2 Workflow diagram of step in data aggregation, analysis, representation, etc., in landslide susceptibility mapping

geomorphology, geology, landuse/landcover of the study area were prepared from various sources. Cartosat- 1 stereo data of $2 \mathrm{~m}$ resolution provide one of the most complete, high-resolution digital elevation model (DEM) of the Earth [11] as it is an ideal data-set for precise terrain analysis that is used to generate slope map and to derive the hypsometric integral attribute of the area under investigation. From IRS P6 (LISS III), data lineament and landuse/landcover map were prepared using the image processing method in ERDAS IMAGINE. Then, demarcation of drainage networks was based on topographical map numbers $49 \mathrm{M} / 14$, $49 \mathrm{M} / 15$, and $49 \mathrm{M} / 10-\mathrm{M} / 6$ on a $1: 50,000$ scale published by Survey of India. The hard copy of the topographic map was scanned and exported in ERDAS IMAGINE to do georeferencing. After georeferencing, the on-screen digitization process was carried out using ARC GIS 10.3. Density is the total length/unit area, and the generation of drainage density and the lineament density map was carried out in the ArcGIS line density tool. The geology and soil data used are from secondary sources (GSI and NBSS). Figures 5, $6,7,8,9,10,11$, and 12 show details of thematic layers generated for overlay analysis to develop an LSM for the study area.
In ANP, all the thematic layers and sub-units are represented as criteria and nodes, respectively (Fig. 3). To obtain normalized weight, ranking given to each factor and sub-units in Satty's scale of 1-9 using ANP (Analytical network process) and the goal assigned is landslide susceptibility mapping and a questionnaire method of pairwise comparison (Fig. 4) was carried out. Satty's scale score of 1 represents equal importance, and 9 represents the extreme importance of one factor over the other [25]. In the questionnaire method, the comparisons are done by answering the question "How important is one criterion than the other" with respect to the specified goal (Fig. 4). After node comparison the inconsistency obtained is 0.16615 , inconsistency $<0.1$ is acceptable and reconsideration of the matrix is not required.

The normalized weight of each parameter and its feature classes obtained after the ANP pairwise comparison is shown in Table 1. Appropriate weights are conferred on each of the attributes such as rainfall, slope, soil, geomorphology, drainage density, lineament density, geology, and hypsometric integral in proportion to their degree of influence on the slope failure regime. A factor of a higher weight obviously deemed to have a larger impact and a 


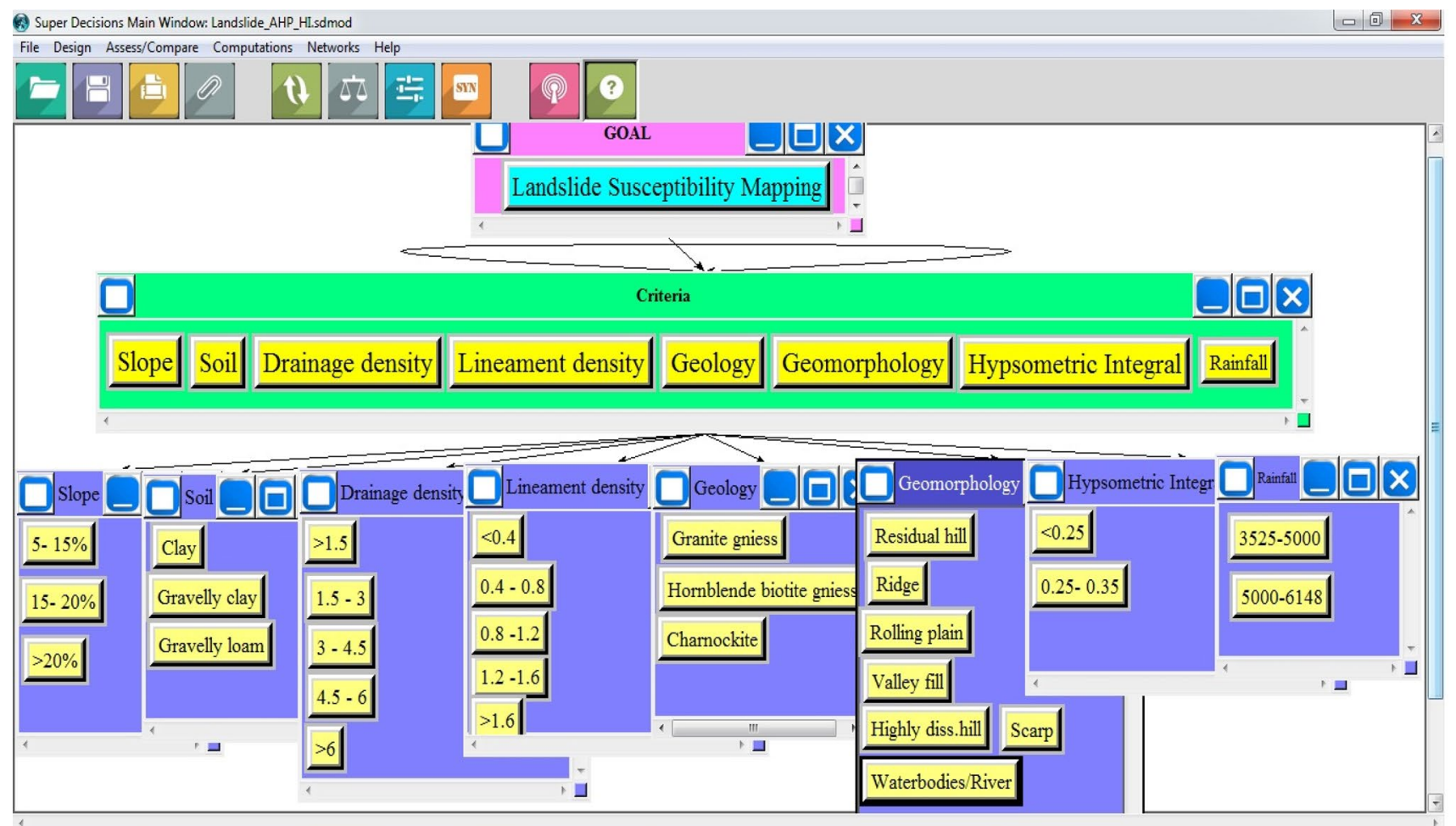

Fig. 3 Decision network design for assigning weight to landslide causative factor

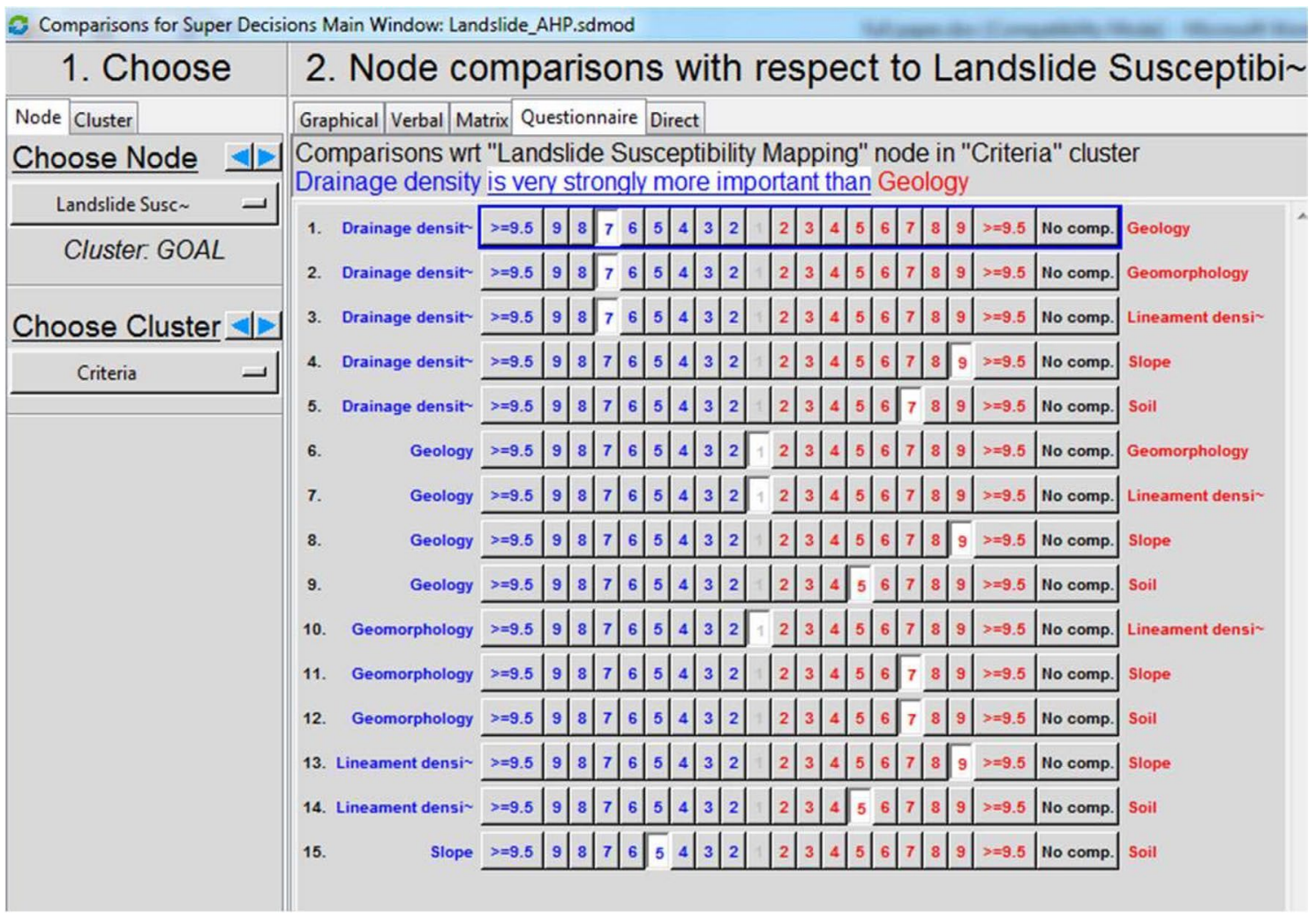

Fig. 4 Questionnaire mode for comparing nodes in the criteria 
Table 1 Relative weight and areal extent of various thematic layers and their corresponding classes

\begin{tabular}{|c|c|c|c|c|c|}
\hline No & Thematic layers & $\begin{array}{l}\text { Normal- } \\
\text { ized } \\
\text { weight }\end{array}$ & Sub-domains/map units & $\begin{array}{l}\text { Areal } \\
\text { extent } \\
\left(\mathrm{km}^{2}\right)\end{array}$ & $\begin{array}{l}\text { Normalized } \\
\text { weight (from } \\
\text { ANP) }\end{array}$ \\
\hline \multirow[t]{2}{*}{1} & Rainfall & 0.327 & $3525-5000$ & 206 & 0.3998 \\
\hline & & & $5000-6148$ & 112 & 0.5929 \\
\hline \multirow[t]{3}{*}{2} & Slope & 0.327 & $5-15 \%$ & 103 & 0.0896 \\
\hline & & & $15-20 \%$ & 95 & 0.2193 \\
\hline & & & $>20$ & 120 & 0.6920 \\
\hline \multirow[t]{2}{*}{3} & Hypsometric Integral & 0.167 & $<0.25$ & 110 & 0.2998 \\
\hline & & & $0.25-0.35$ & 208 & 0.6929 \\
\hline \multirow[t]{3}{*}{4} & Soil & 0.132 & Clay & 136 & 0.2052 \\
\hline & & & Gravely clay & 167 & 0.3192 \\
\hline & & & Gravely loam & 15 & 0.5408 \\
\hline \multirow[t]{5}{*}{5} & Drainage density & 0.126 & $<1.5$ & 24 & 0.0286 \\
\hline & & & $1.5-3$ & 79 & 0.0526 \\
\hline & & & $3-4.5$ & 78 & 0.0921 \\
\hline & & & $4.5-6$ & 67 & 0.3828 \\
\hline & & & $>6$ & 70 & 0.5337 \\
\hline \multirow[t]{5}{*}{6} & Lineament density & 0.0318 & $<0.4$ & 24 & 0.0333 \\
\hline & & & $0.4-0.8$ & 89 & 0.0634 \\
\hline & & & $0.8-1.2$ & 94 & 0.1290 \\
\hline & & & $1.2-1.6$ & 77 & 0.2615 \\
\hline & & & $>1.6$ & 34 & 0.5128 \\
\hline \multirow[t]{6}{*}{7} & Geomorphology & 0.0318 & Valley fill & 8 & 0.0216 \\
\hline & & & Rolling plain & 85 & 0.0242 \\
\hline & & & Highly dissected hill & 207 & 0.6742 \\
\hline & & & Residual hill & 2 & 0.2847 \\
\hline & & & Ridge & 2 & 0.0306 \\
\hline & & & Waterbodies/river & 13 & 0.0282 \\
\hline \multirow[t]{3}{*}{8} & Geology & 0.0318 & Charnockite & 76 & 0.3421 \\
\hline & & & Granite gneiss & 10 & 0.2452 \\
\hline & & & Hornblende-biotite gneiss & 232 & 0.4721 \\
\hline
\end{tabular}

factor with a lower weight would have a lower influence on the stability of the slope. The normalized weights of each theme and its sub-unit with the areal extent are shown in Table 1. To perform GIS-overlay analysis, the ranking was given to each thematic layer and its sub-units based on the normalized weight obtained after MCDM-ANP analysis and then GIS-based overlay analysis performed and classified the study area into stable, moderately stable, moderately unstable, and unstable zones. The mathematical operation happening behind the GIS process during weighted overlay analysis for landslide susceptibility mapping is shown as Eq. 1. lineament density; GM, geomorphology; GG, geology; RF, Rainfall; 'w,' normalized weight of a theme; 'wi,' normalized weight of the individual features of a theme.

\section{Results and discussion}

\subsection{Multi-influencers to accelerate landslide}

The selection of factors controlling landslide is completely based on the nature of the area; in this study, factors such as slope, hypsometric integral, soil, drainage density, line- where LSM, landslide susceptibility mapping; SL, slope; SO, soil; $\mathrm{HI}$, hypsometric integral; DD, drainage density; LD, ament density, geology, geomorphology, and rainfall were considered for landslide susceptibility mapping. In eight 


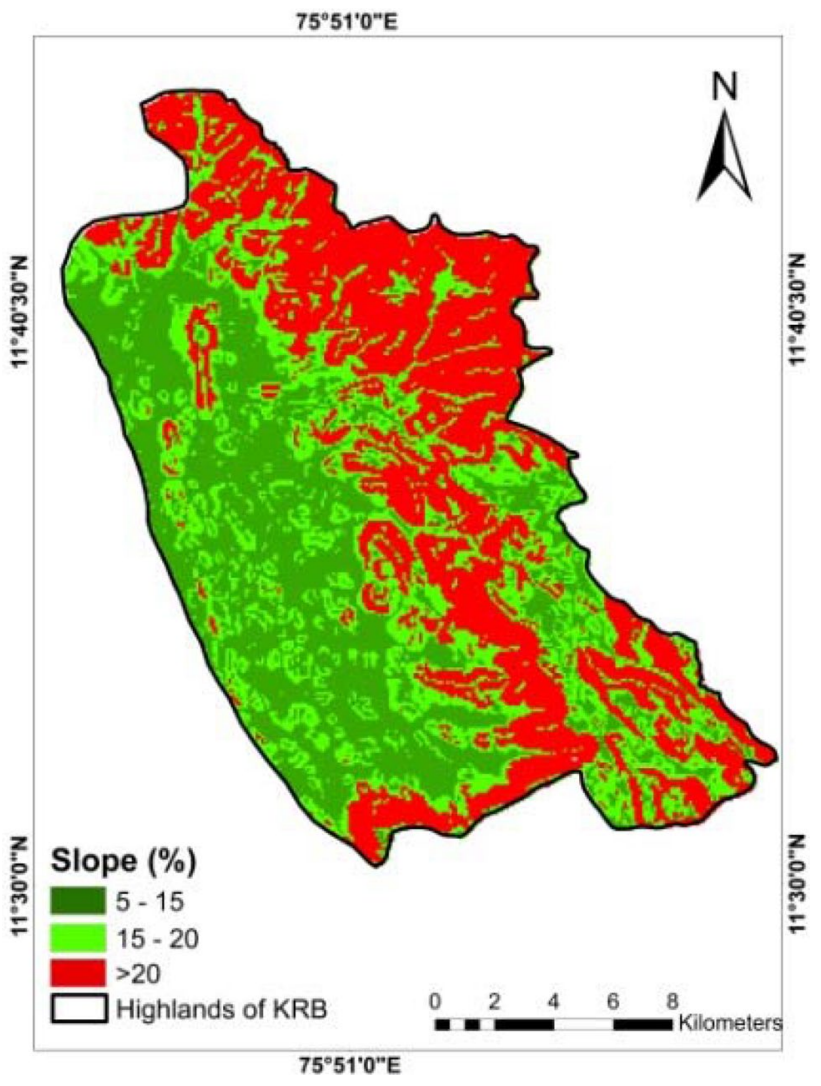

Fig. 5 Slope map

intrinsic variables considered for the analysis, slope factor and rainfall of acquired high weight value $(0.327)$ followed by it hypsometric integral $(0.167)$ and soil $(0.132)$ have given high priority. The hydrological factor, drainage density have received a weight of 0.126 . The geology, geomorphology, and lineament density have equal importance, so the weight obtained for these is 0.0318 .

The Slope (SL) map of the entire study area extracted from Cartosat-1 high-resolution Stereo data is classified into three categories based on the percentage of slope, $5-15 \%, 15-20 \%$, and $>20 \%$. The slope of the area is an important factor in landslide occurrence, if the slope is steep, chances of occurrence of the landslide are high than the gentle slope region [23]. The normalized weight obtained for slope factor after ANP analyses is 0.327, and slope class $>20 \%$ with the highest weight obtained $(0.6920)$ is grouped under a high rank by considering the general fact, chance and frequency of landslide occurrence increase with increasing slope (Fig. 5) due to the high runoff in the steep slope. Slope classes $5-15 \%$ and $15-20 \%$ have given second and third ranking considering the weight 0.2193 and 0.0896 . The areal extent of slope class $>20$ is $122 \mathrm{~km}^{2}, 15-20 \%$ have $95 \mathrm{~km}^{2}$ and $5-15 \%$ have $103 \mathrm{~km}^{2}$ (Table 1 ).

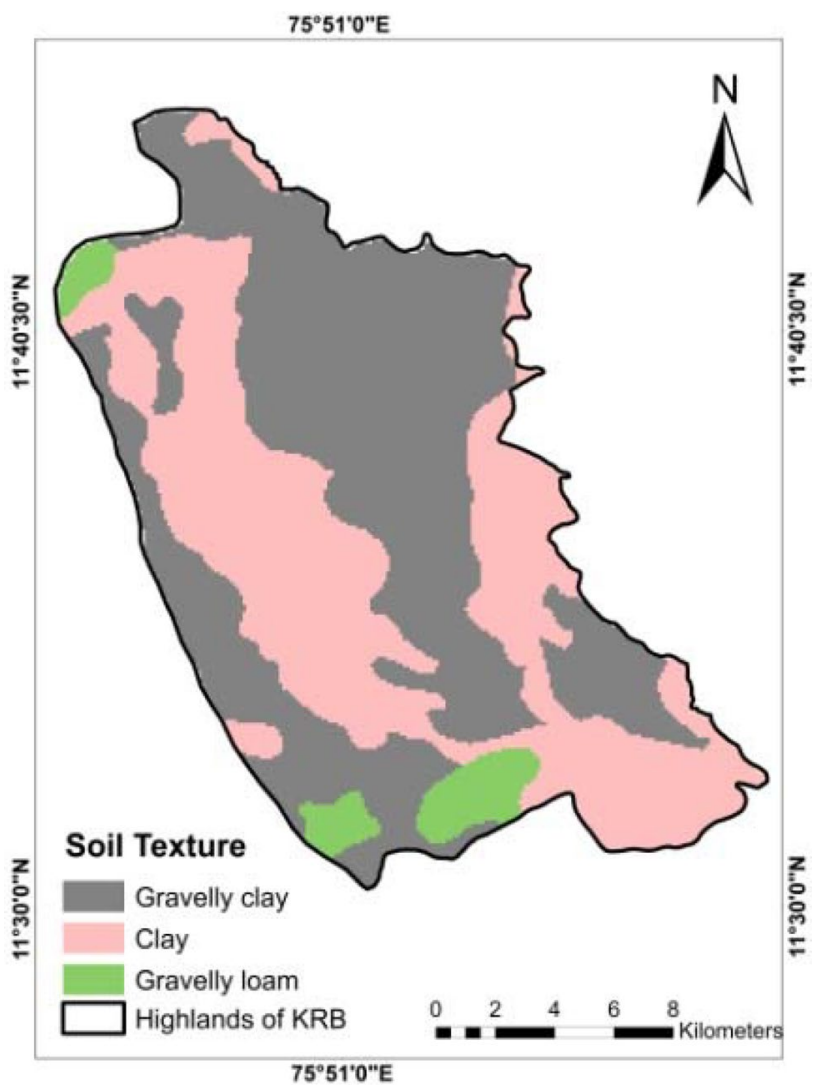

Fig. 6 Soil map

The soil properties of an area have a significant role in accelerating the slope failures with other favorable conditions [34]. The infiltration rate of the soil depends on its texture and then soil texture map of the study area prepared it reveals three main soil textures, namely clay, gravelly clay, and gravelly loam (Fig. 6) with an areal extent of $136 \mathrm{~km}^{2}, 167 \mathrm{~km}^{2}$, and $15 \mathrm{~km}^{2}$, respectively (Table 1 ). The rate of infiltration is very less for these particular soil textures and which causes it to slide. Based on the weight obtained for each class, clay (0.2052), gravelly clay (0.3192), and gravelly loam (0.5408) rank assigned while doing GIS overlay analysis.

Drainage density (DD) is a good index for disaster management as the increasing drainage density always responsible for the slope failure [14] because it indicates the imperviousness of strata, high rainfall, active stream incision, and these are directly related to mass movements. Drainage density (DD) is the total length of streams of all orders per drainage area and indicates the closeness of the spacing of channels (Horton 1932). The drainage density map of this study area is reclassified into four category, i.e., $>6$ (very high), 4.5-6 (high), 3-4.5 (medium), 1.5-3 (low), and $<1.5$ (very low) km/ $\mathrm{km}^{2}$ (Fig. 7). The weight obtained for drainage density 


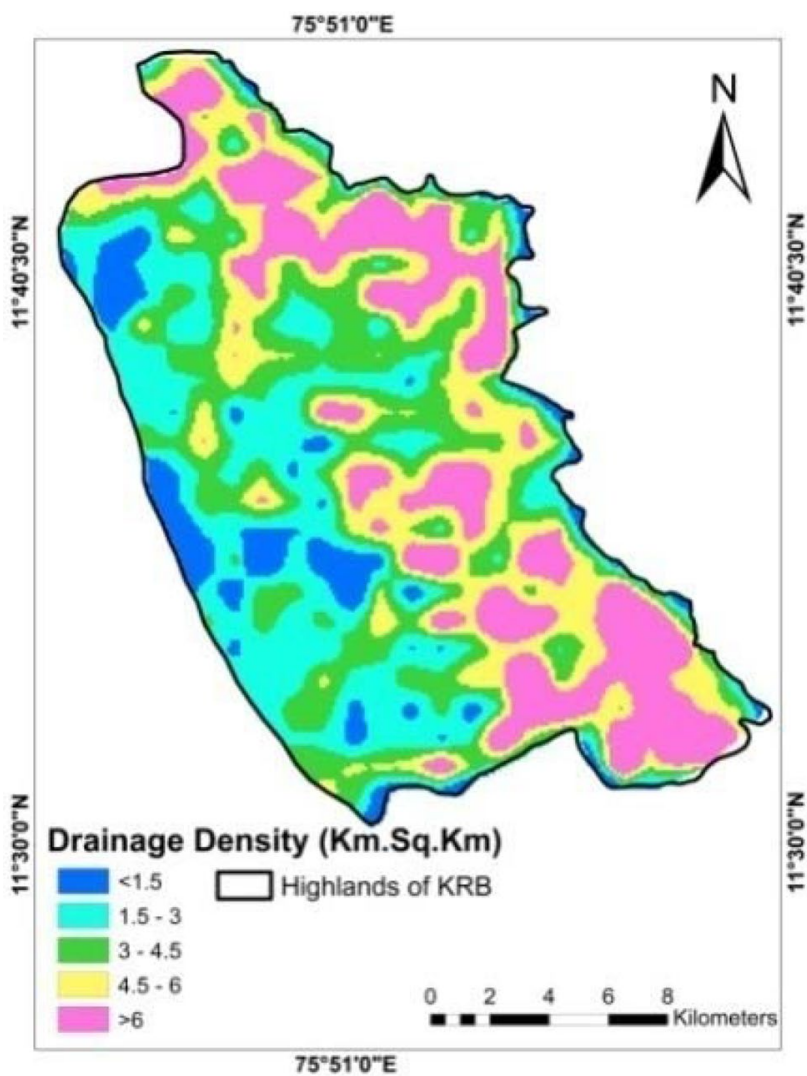

Fig. 7 Drainage density map

after ANP analysis is 0.126 , for its sub-units the highest weight attained by areas with very high drainage density (0.5337) covering an area of $70 \mathrm{~km}^{2}$. Areas having high density are more prone to landslide because of the less infiltration and greater surface run off. The weight assigned for high $\left(67 \mathrm{~km}^{2}\right)$, medium $\left(78 \mathrm{~km}^{2}\right)$, low $\left(79 \mathrm{~km}^{2}\right)$, and very low $\left(24 \mathrm{~km}^{2}\right)$ drainage density zones are $0.3828,0.0921,0.0526,0.0286$, respectively.

Lineament density (LD) of an area can indicate a weak zone, presence of structural features like joints, fractures, etc., and extensive weathering will reduce the strength and stability of the rock to resist landslide, and it may cause most dangerous landslide with heavy rocks and soil [28]. Areas with high lineament density, $>1.6$ in highlands of KRB, are plane of weakness; any disturbance (both natural and anthropogenic) can result in slope failure eventually. The lineament density map is classified into four type, i.e., $>1.6$ (very high), 1.2-1.6 (high), 0.8-1.2 (medium), 0.4-0.8 (low), and $<1.4$ (very low) $\mathrm{km} / \mathrm{km}^{2}$ (Fig. 8). Very high lineament density class with $34 \mathrm{~km}^{2}$ attained a normalized weight value 0.5128 has given a high ranking during GIS overlay analysis and followed by it weightage for high, medium, low, and very

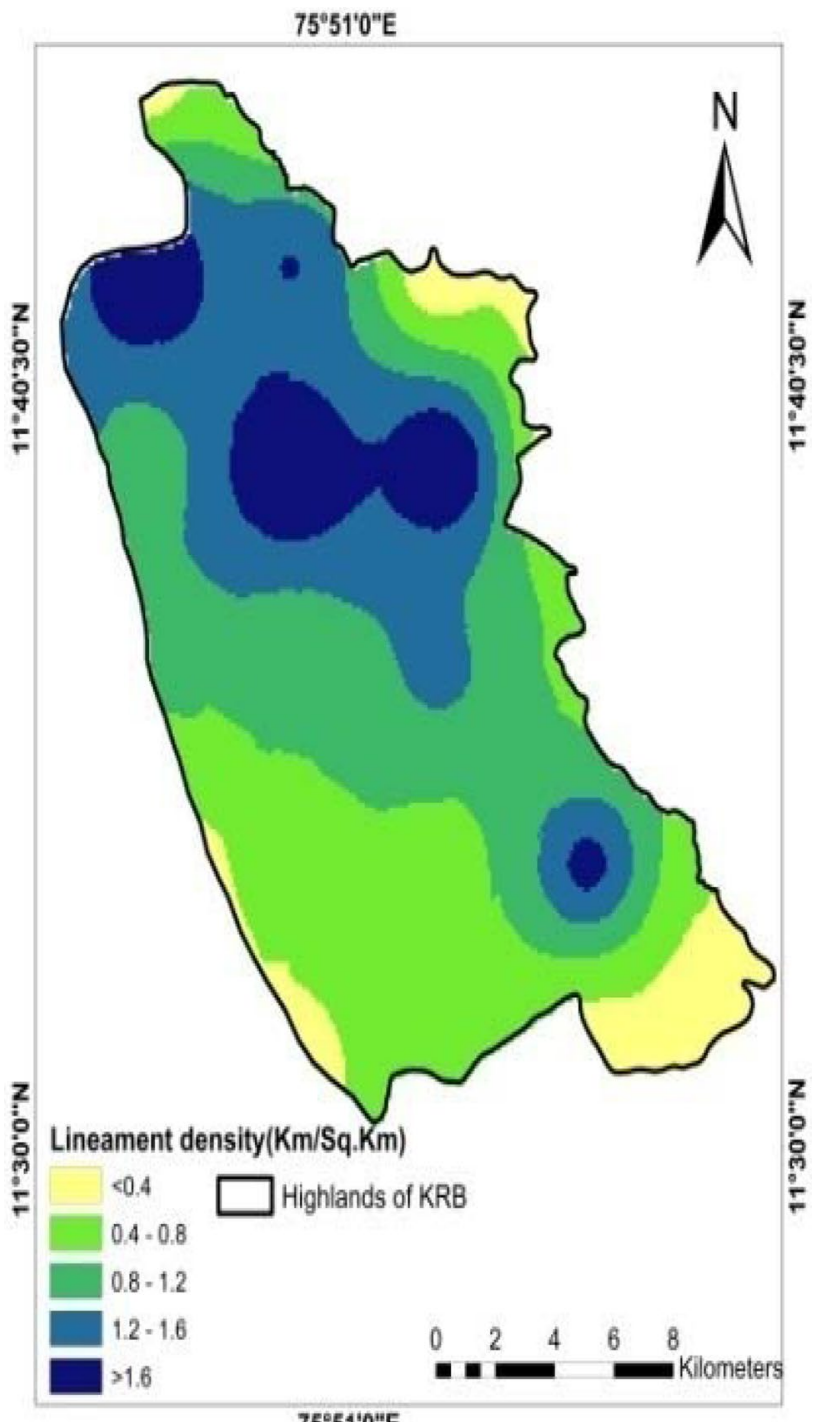

$75^{\circ} 51^{\prime} 0^{\prime \prime E}$

Fig. 8 Lineament density map

low LD zones are $0.2615,0.1290,0.0634,0.0333$ and its areal extent is $77 \mathrm{~km}^{2}, 94 \mathrm{~km}^{2}, 89 \mathrm{~km}^{2}, 24 \mathrm{~km}^{2}$ (Table 1).

The geomorphology (GM) units identified in the highlands of KRB in the decreasing order for the probability of landslide are highly dissected residual hills and structural hills, residual mound complex, linear ridges and scarps, rolling plains, valley fills (Fig. 9). The normalized weight for each unit is $0.6742,0.2847,0.0177,0.0242$, and 0.0216 . Highly dissected hills cover $207 \mathrm{~km}^{2}$ of the area, and which is of denudational origin. The geomorphic features which are of denudational origin are more prone to landslide than that of structural origin [3].

The geology (GG) units, crystalline rocks of the Archean age noticed here and the major rocks hornblende-biotite gneisses $\left(232 \mathrm{~km}^{2}\right)$, Charnockite $\left(77 \mathrm{~km}^{2}\right)$, and granite $\left(10 \mathrm{~km}^{2}\right)$, cover the area (Fig. 10). Strong, stable, and hard 


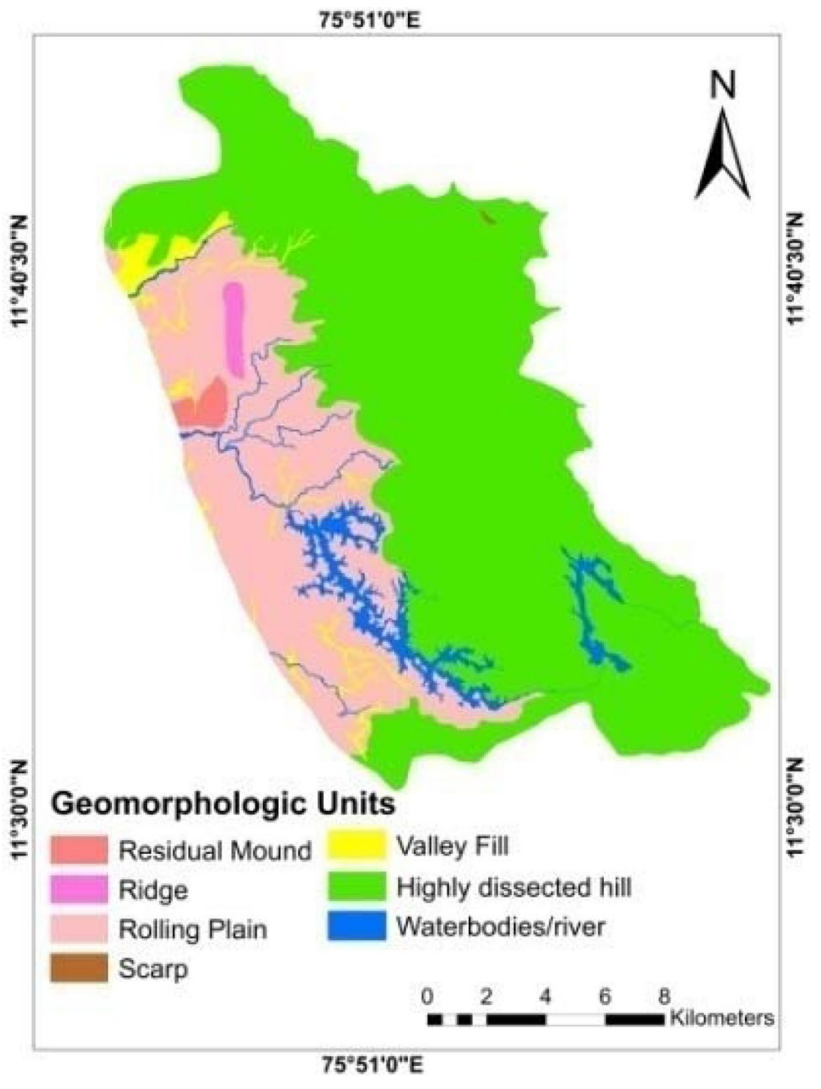

Fig. 9 Geomorphology map

rocks like granite, charnockite can impart stability to the slope, and the region is less susceptible to landslide; in this study area, landslides are not reported so far in the northeastern region with charnockite formation. The major portion covering hornblende-biotite gneiss rock type is more prone to landslide due to its weathering properties. Then, weight acquired for each unit is $0.4721,0.3421$, and 0.2452 , respectively. It is observed that in parts of Western Ghats in Kerala most of the landslide events were associated with highly weathered hornblende gneiss (about 75\%) and the remaining $25 \%$ in granite gneiss [24].

Hypsometric integral $(\mathrm{HI})$ is a geoindicator of geomorphologic hazards, $\mathrm{HI}$ value $<0.25$ indicates an old or monadnock stage of a particular landform and 0.25-0.35 shows a mature stage of development (Fig. 11). While considering the stage of development, mature stage landform is most susceptible to runoff and erosion because more upland or soil cover is remaining here than old stage watersheds. The availability of material on the slope can be responsible for landslide; $\mathrm{HI}=0.35$ indicates only $35 \%$ of the landmass is remaining and $65 \%$ volume got eroded. As per hypsometric integral values, in mature stage landform material is available on the slope (25-35\%) to be eroded is high to attain a steady-state equilibrium. Therefore, the

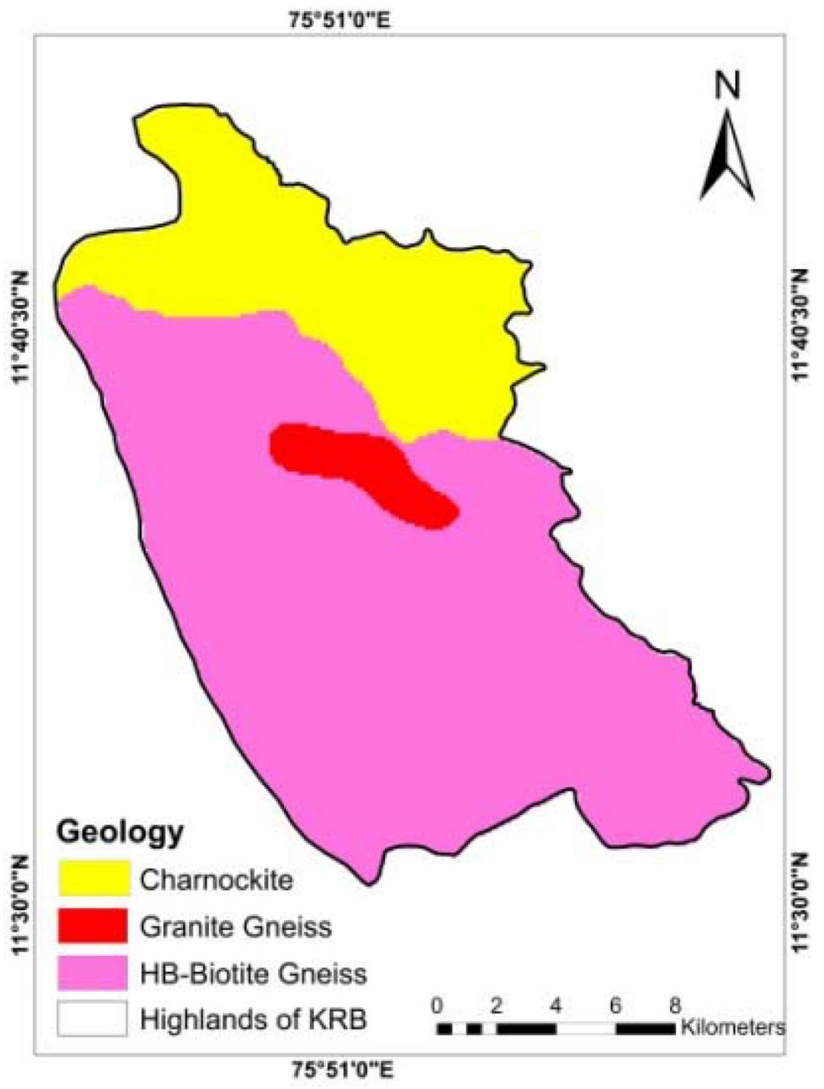

Fig. 10 Geology map

chance of occurrence of landslide events will be more in these landforms with dominant high-energy fluvial process.

The annual mean rainfall (RF) varies from 6148 to $3525 \mathrm{~mm}$ (Fig. 12) in the highland and lowland, the highest rainfall in Kozhikode district noticed in the Kakkayam dam site with more than $4500 \mathrm{~mm}$ of annual rainfall since 2000 (CGWB, Groundwater Information Booklet, 2013). Then, normalized weight for rainfall classes after ANP analysis is 0.3998 and 0.5929 .

\subsection{Landslide susceptibility map}

The landslide susceptibility analysis can provide information on the susceptibility of the topography to slope failures; therefore, it can be used for the soil loss estimation, the localization of new building sites, and before implementing disaster management plans [Sarkar]. A systematic analysis using ANP on weighted parameters has produced a suitable landslide susceptibility map for the highland of a tropical river basin (Kuttiyadi river basin, Kerala) in raster format using the overlay method of spatial analyst tool in ArcGIS platform. The LSM in the study area was grouped as unstable, moderately unstable, moderately stable, 


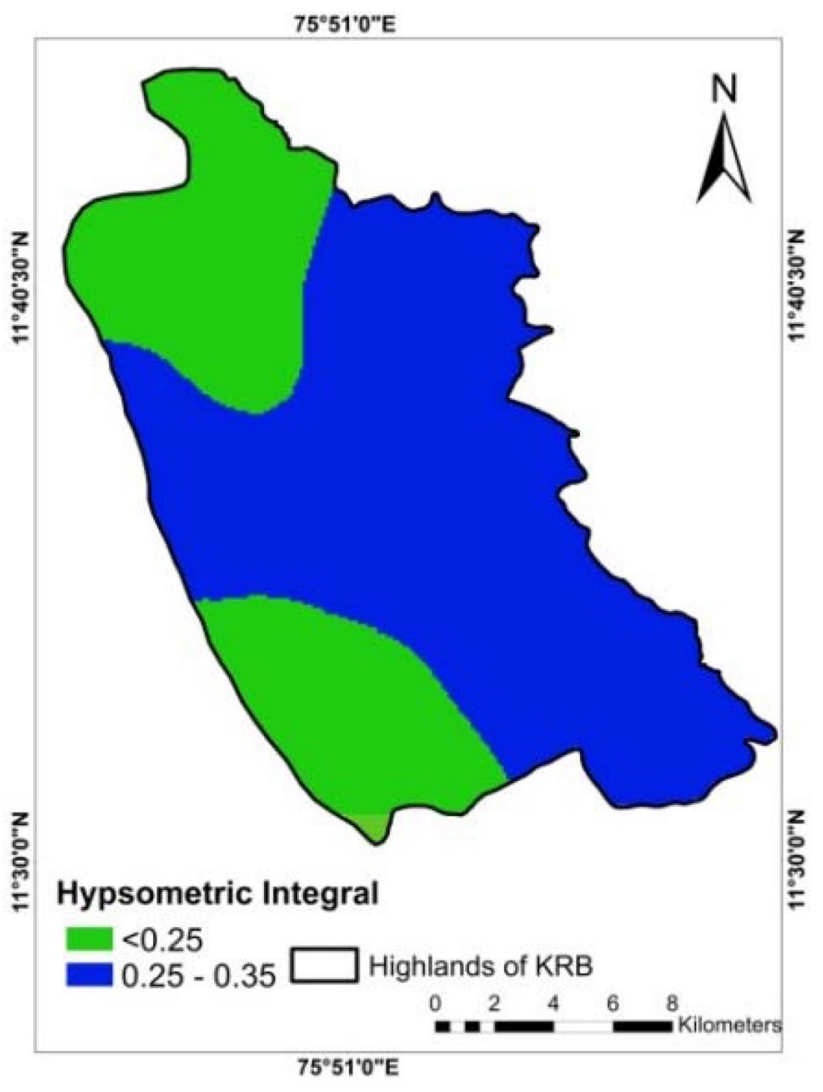

Fig. 11 Hypsometric integral map

and stable, depending on their role to trigger landslides (Fig. 13). The LSM reveals that unstable area spread over the Eastern tracts of KRB with dissected hills, high drainage density, slope greater than $20 \%$, and gravely clay soil texture. The stable zone occupies in an aerial extent of $68 \mathrm{~km}^{2}$ (Table 2) where the slope class is between 5 and $15 \%$ and drainage density and lineament density are very less.

\subsection{Data validation}

Both historical and recent landslides in this study area validate the particular study. Even though small landslide events occur in KRB during monsoons, the most devastating hazards previously reported here are Pasukkadavu (June 19, 1992, and June 29, 1994), Nittukottu mala (August 2004), Muthukad, Kuttiyadi (August 4, 2004), Kurachunde (June 26, 1990), and Kakkayam dam site (Details from, Kerala State Disaster Management Authority). Acres of agriculture lands destroyed at these locations, and also many people lost their life. Landslide becomes common in Kakkayam dam road during monsoons recently occurred in August 2018 (Fig. 13) and 2020. The stages of development of KRB identified through hypsometric analysis and found that sub-watersheds occurring in the highland

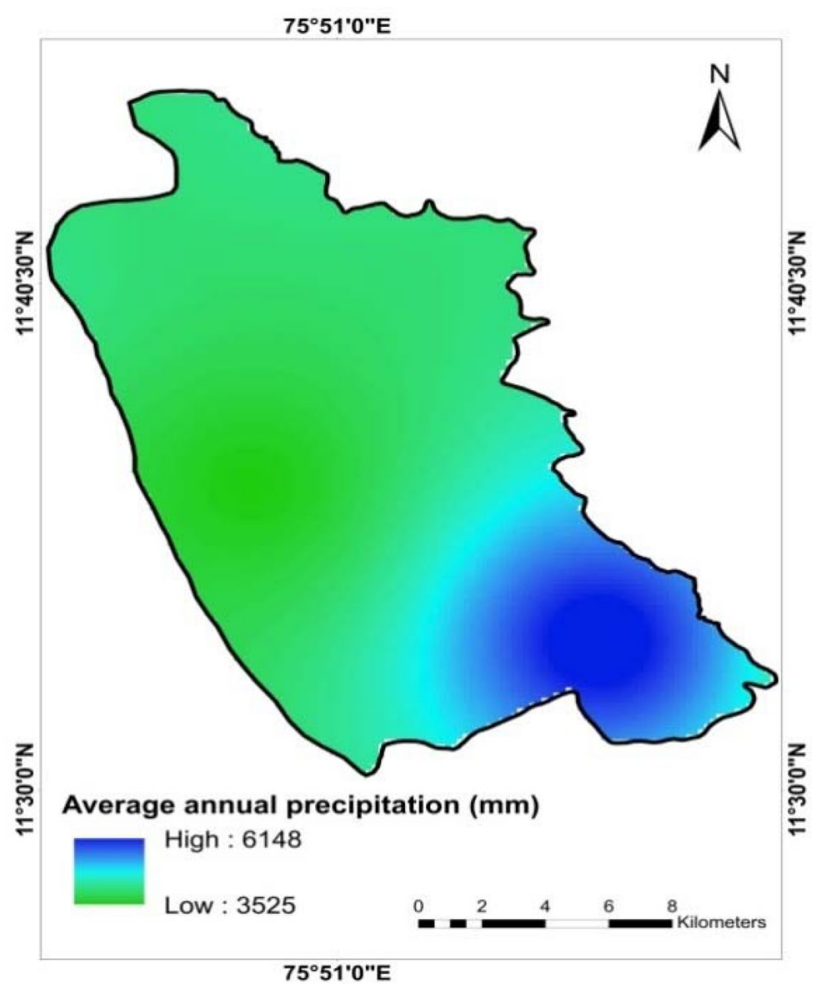

Fig. 12 Annual rainfall map

region, SW-I, II, and V are in the old stage and SW-III, SW-IV in the mature stage [13]. The mature stage landform has more upland and active fluvial processes than the old stage showing repeated landslide events; except one location (Kurachunde), all other landslide events have occurred in unstable areas of mature stage landforms in the highlands of KRB.

\section{Conclusion}

The landslide susceptibility map can provide details on the stability of the area; more stable means less prone to landslide hazards. This work was carried out based on several previous works related to the significance of remote sensing and GIS to generate landslide susceptibility map (LSM) in this study LSM for the part of the Western Ghats in the Kuttiyadi river basin of Northern Kerala prepared. Seven intrinsic variables considered for the analysis after the systematic analysis of these parameters using analytical network process (ANP), the slope factor, and hypsometric integral $(\mathrm{HI})$ of each sub-watersheds considered with high normalized weight value $(0.527)$ followed by its soil texture $(0.252)$ has given high priority. The hydrological factor, drainage density, has received a weight of 0.126 . The geology, geomorphology, and lineament density have 


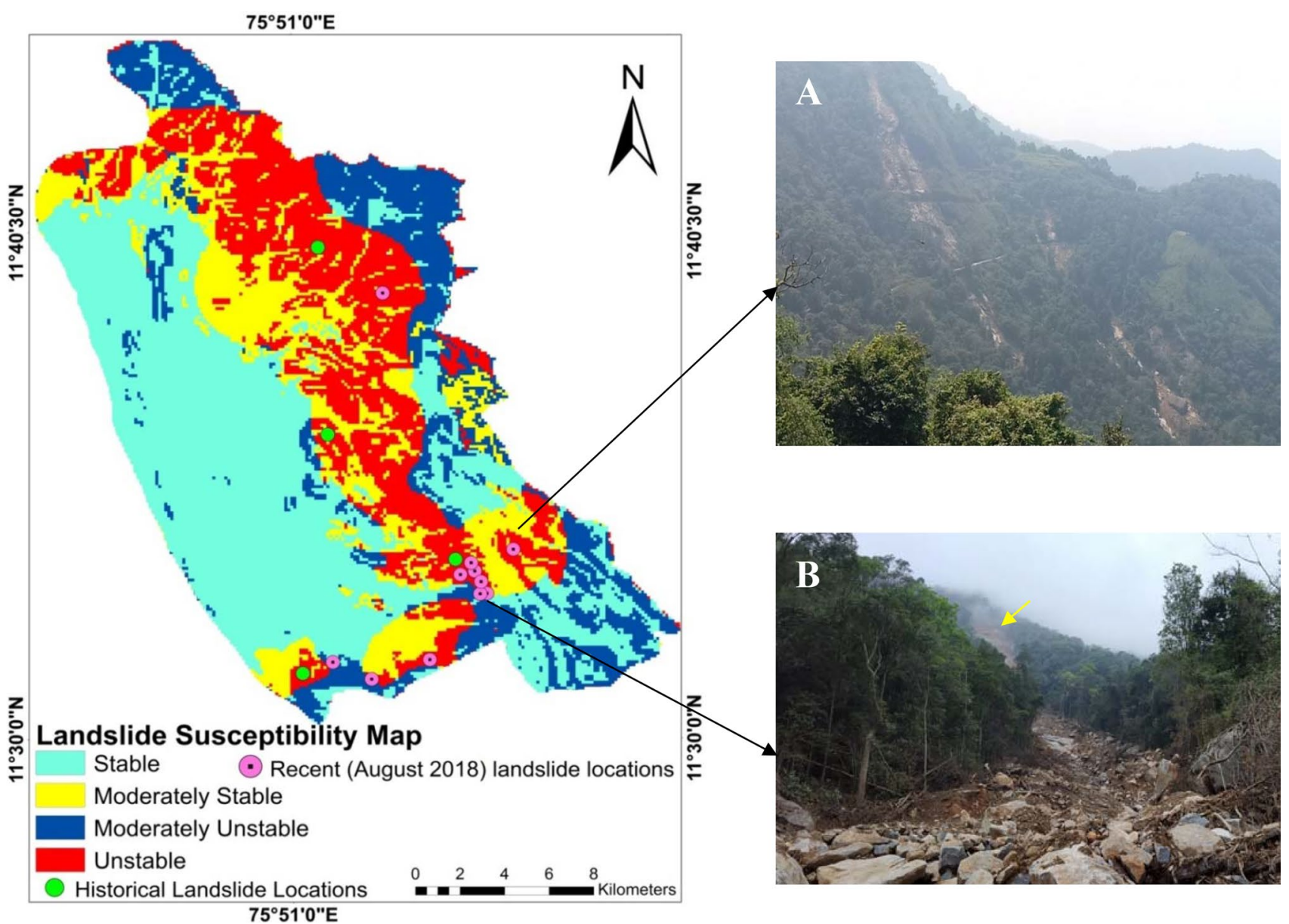

Fig. 13 Landslide susceptibility map, Highlands of KRB. Examples of landslides mapped in study area showing. a Distant view of the debris slide, $\mathbf{b}$ Yellow arrow points to the scarp of the slide

Table 2 Landslide susceptibility zones and areal extent

\begin{tabular}{lll}
\hline Landslide susceptibility zones & Extent $\left(\mathrm{km}^{2}\right)$ & Area (in \%) \\
\hline Unstable & 121 & 39 \\
Moderately unstable & 76 & 23 \\
Moderately stable & 54 & 17 \\
Stable & 68 & 21 \\
\hline
\end{tabular}

equal importance, and then, the weightage obtained for these is 0.032 .

Based on the landslide susceptibility map, the study area $\left(318 \mathrm{~km}^{2}\right)$ is grouped as unstable $\left(121 \mathrm{~km}^{2}\right)$, moderately unstable $\left(76 \mathrm{~km}^{2}\right)$, moderately stable $\left(54 \mathrm{~km}^{2}\right)$, and stable $\left(68 \mathrm{~km}^{2}\right)$ covering $39 \%, 34 \%, 17 \%$, and $21 \%$ of this area, respectively (Fig. 13). It noted that all the landslides so far occurred in this study area are in hornblende-biotite gneiss lithology; it can be considered as most triggering natural factors responsible for landslide events here along with heavy rainfall. The past landslide inventory data proved the accuracy of the analysis as the majority of it falls in unstable areas identified through this study. The LSM generated for this study can utilize to aware of the public and local authorities on the chances of occurrence of this geohazard and stay with alert can reduce the high risk and damages of this most devastating geohazard. The information obtained on the stability of the area in each sub-watershed also can utilize before implementing any conservation and mitigation measures here.

Acknowledgements The authors are grateful to the Executive Director of Centre for Water Resources Development and Management (CWRDM), Kozhikode for the facilities provided, to prepare this paper.

Code availability Not applicable.

\section{Compliance with ethical standards}

Conflict of interest On behalf of all authors, the corresponding author states that there is no conflict of interest. 
Availability of data and materials Not applicable.

\section{References}

1. Akgun H (2003) Remediation of the geotechnical problems of the Hasankeyf Historical Area, southeastern Turkey. Environ Geol 44(5):522-529. https://doi.org/10.1007/s0025 4-002-0743-4/

2. Akgün H, Muratl S, Koçkar MK (2014) Geotechnical investigations and preliminary support design for the Geçilmez tunnel: a case study along the Black Sea Coastal Highway, Giresun, northern Turkey. Tunn Undergr Space Technol 40:277-299

3. Akgun A (2012) A comparison of landslide susceptibility maps produced by logistic regression, multi-criteria decision, and likelihood ratio methods: a case study at Izmir, Turkey. Landslides 9:93-106

4. Anju K, Greena S, Nikhila P, Shijo J, Geeja KG, Vinu P (2018) Landslide Hazard Zonation (LHZ) Mapping of Attappady, Kerala using GIS. Int Res J Eng Technol 5(3):3808-3812

5. Azarafza M, Akgün H, Asghari-Kaljahi E (2016) Assessment of rock slope stability by slope mass rating (SMR): a case study for the gas flare site in Assalouyeh, South of Iran. Geomech Eng 13(4):571-584

6. Azarafza M, Asghari-Kaljahi E, Akgün H (2017) Assessment of discontinuous rock slope stability with block theory and numerical modeling: a case study for the South Pars Gas Complex, Assalouyeh, Iran. Environ Earth Sci 76(11):397

7. Azarafza M, Ghazifard A, Akgün H, Asghari-Kaljahi E (2018) Landslide susceptibility assessment of South Pars Special Zone, southwest Iran. Environ Earth Sci 77(24):805

8. Azarafza M, Nanehkaran YA, Rajabion L, Akgün H, Rahnamarad J, Derakhshani R, Raoof A (2020) Application of the modified Q-slope classification system for sedimentary rock slope stability assessment in Iran. Eng Geol 264:105349

9. Chalkias C, Maria FM, Polykretis C (2014) GIS-based landslide susceptibility mapping on the Peloponnese Peninsula, Greece. Geosci J 4:176-190

10. Erener A, Lacasse, S (2007) Landslide susceptibility mapping using GIS, south-eastern part of Norway. https://www.resea rchgate.net/publication/228826222. Accessed 20 Feb 2020

11. Evans GA, Ramachandran B, Zhang Z, Bailey GB, Cheng $P$ (2008) An accuracy assessment of CartoSat-1 stereo image data-derived digital elevation models: a case study of the Drum Mountains, Utah. In: International archives of the photogrammetry, remote sensing and spatial information sciences, vol XXXVII. Part B1. Beijing

12. Foumelis M, Lekkas E, Parcharidis I (2004) Landslide susceptibility mapping by GIS-based qualitative weighting procedure in Corinth area. Bull Geol Soc Greece 99:99. https://doi. org/10.12681/bgsg. 16840

13. Gopinath G, Swetha TV, Ashitha MK (2014) Elicitation of erosional signature of a tropical river basin with high-resolution stereo data. Appl Geomat. https://doi.org/10.1007/s1251 8-014-0127-y

14. Hasegawa S, Nonomura A, Nakai S, Dahal RK (2013) Drainage density as rainfall induced Landslides Susceptibility Index in small catchment area. Int J Landslide Environ 1(1):27-28

15. Highland LM, Bobrowsky P (2008) The landslide handbooka guide to understanding landslides. US Geological Survey Circular Press, Reston

16. Iverson NR, Mann JE, Iverson RM (2010) Effects of soil aggregates on debris-flow mobilization: results from ring-shear experiments. Eng Geol 114:84-92
17. Liang W, Zhuang D, Jiang D, Pan J, Ren H (2012) Assessment of debris flow hazards using a Bayesian Network. Geomorphology. https://doi.org/10.1016/j.geomorph.2012.05.00

18. Lollino G, Giordan D, Giordan D, Crosta GB, Corominas J, Azzam R, Wasowski J, Sciarra N, Landslide processes. Engineering Geology for Society and Territory, vol 2

19. Okalp K, Akgün H (2016) National level landslide susceptibility assessment of Turkey utilizing public domain dataset. Environ Earth Sci 75(9):847

20. Oral DG, Akgün H, Koçkar MK (2015) Characterization and assessment of large landslide movement along the Bursaİnegöl-Bozüyük highway in Turkey. In: Engineering Geology for Society and Territory, vol 2

21. Othman AA, Gloaguen R, Andreani L, Rahnama M (2015) Landslide susceptibility mapping in Mawat area, Kurdistan Region, NE Iraq, a comparison of diffeerent statistical models. Nat Hazard Earth Syst 3:1789-1833

22. Predrag M, Goran V (2014) Impact of weathering on slope stability in soft rock mass. J Rock Mech Geotech Eng 6(3):240-250

23. Saha AK, Gupta RP, Arora MK (2002) GIS-based landslide hazard zonation in the Bhagirathi (Ganga) valley, Himalayas. Int J Remote Sens 23(2):357-369

24. Sajinkumar KS, Pradeepkumar AP, Anbazhagan Siddan (2011) Weathering and landslide occurrences in parts of Western Ghats, Kerala. J Geol Soc India 78:249-257

25. Saaty TL (2005) Theory and applications of the analytic network process. RWS Publications, Pittsburgh

26. Shahabi H, Ahmad BB, Khezri S (2012) Landslide susceptibility mapping using image satellite and GIS technology. Int J Eng Res Technol (IJERT) 1(6):2278-0181

27. Sujatha ER, Rajamanickam V (2011) Landslide susceptibilitymapping of Tevankarai Ar Sub-Watershed, Kodaikkanal, Taluk, India, using weighted similar choice fuzzy model. Nat Hazards 59:401-425. https://doi.org/10.1007/s11069-011-9763-2

28. Sujatha ER, Sridhar V (2017) Mapping debris flow susceptibility using analytical network process in Kodaikkanal Hills, Tamil Nadu (India). J Earth Syst Sci. https://doi.org/10.1007/s1204 0-017-0899-7

29. Swetha TV, Gopinath Girish, Thrivikramji KP, Jesiya NP (2017) Geospatial and MCDM tool mix for identification of potential groundwater prospects in a tropical river basin, Kerala. Environ Earth Sci 76:428. https://doi.org/10.1007/s1266 5-017-6749-8

30. Terlien MTJ (1998) The determination of statistical and deterministic hydrological landslide-triggering thresholds. Environ Geol 35(2-3):124-130

31. Tseng CM, Lin CW, Hsieh WD (2015) Landslide susceptibility analysis using event-based landslide inventories. Nat Hazard Earth Syst 3:1137-1173

32. Vahidnia $\mathrm{MH}$, Alesheikh $\mathrm{AA}$, Alimohammadi $\mathrm{A}$, Hosseinali $F$ (2009) Landslide hazard zonation using quantitative methods in GIS. Int J Civ Eng 7(3):176-189

33. Xia FT, Yong L, Quan YT, Feng HS (2019) Landslides distribution at tributaries with different evolution stages in Jiangjia Gully. Nat Hazards Earth Syst Sci Discuss. https://doi.org/10.5194/ nhess-2019-90

34. Yilmaz $T$ (2017) The effect of soil properties on landslides along Forest road. Eur J Forest Eng 3(1):1-6

35. Zhou CH, Lee CF, Li J, Xu ZW (2002) On the spatial relationship between landslides and causative factors on Latau Island, Hong Kong. Geomorphology 43:197-207

Publisher's Note Springer Nature remains neutral with regard to jurisdictional claims in published maps and institutional affiliations. 